\title{
Macroinvertebrates responses based on chemical and physical variables in urban streams
}

\author{
Germano Henrique Costa Barrilli ${ }^{1,5}$; Natalia Felix Negreiros ${ }^{2,6} ;$ Odete Rocha ${ }^{3,7}$ \& José Roberto Verani ${ }^{4,8}$ \\ 1 Universidade Federal de São Carlos (UFSCAR), Centro de Ciências Biológicas e da Saúde (CCBS), \\ Programa de Pós Graduação em Ecologia e Recursos Naturais (PPGERN). São Carlos, SP, Brasil. \\ ${ }^{2}$ Centro Universitário Católico Salesiano Auxilium (UniSalesiano). Araçatuba, SP, Brasil. \\ 3 Universidade Federal de São Carlos (UFSCAR), Centro de Ciências Biológicas e da Saúde (CCBS), \\ Departamento de Ecologia e Biologia Evolutiva (DEBE). São Carlos, SP, Brasil. \\ ${ }^{4}$ Universidade Federal de São Carlos (UFSCAR), Centro de Ciências Biológicas e da Saúde (CCBS), \\ Departamento de Hidrobiologia (DHB). São Carlos, SP, Brasil. \\ ${ }^{5}$ ORCID: http://orcid.org/0000-0001-8625-2759. E-mail: germanohcb@gmail.com (corresponding author) \\ ${ }^{6}$ ORCID: http://orcid.org/0000-0003-4685-0935. E-mail: natalia_felix@yahoo.com.br \\ ${ }^{7}$ ORCID: http://orcid.org/0000-0002-0798-3316. E-mail: doro@ufscar.br \\ ${ }^{8}$ ORCID: http://orcid.org/0000-0001-9197-334X. E-mail: verani@ufscar.br
}

\begin{abstract}
The Land uses and occupations around small watersheds generate negative impacts such as deterioration of water quality, environmental simplification, reduced availability of habitats for species, and loss of biodiversity. Benthic macroinvertebrates are an important aquatic community and are widely used in environmental monitoring actions in aquatic ecosystems, including urban streams, which are still little studied in Brazil. In our study, an urban headwater basin (Monjolinho River Basin) was studied on the benthic community structure, together with the physical and chemical variables of the water, as an environmental monitoring tool calculated by RHDEP, TSI, BMWP indexes and abundance-biomass curves. The results showed a gradient of environmental quality, where the best environments are a consequence of preserving the vegetation cover. These environments (Espraiado and Canchim) present groups sensitive to environmental degradation (Ephemeroptera, Plecoptera and Trichoptera), greater diversity and a better structure in the respective benthic macroinvertebrate assemblages. Among the streams sampled, one is very clean, four are moderately polluted, and one is severely polluted. Thus, considering that these streams' waters are essential for public supply, actions to clean up and recover degraded environments are urgent and a priority.
\end{abstract}

Keywords. Bioindicators; Conservation; Freshwater; Ecology; Monitoring.

\section{INTRODUCTION}

Aquatic ecosystems provide essential services for human needs and suffer negative impacts due to overexploitation caused by human activities. The illegal use and occupation of small hydrographic basins cause deforestation in these areas, resulting in siltation, loss of habitat, environmental contamination, decreased water quality, and biodiversity loss (Siqueira \& Roque, 2010).

The assessments in aquatic ecosystems, previously carried out through the analysis of the water's physical and chemical characteristics, started to consider the responses that the biological communities provided to the different levels of disturbances (Stevenson et al., 1996; Suriano et al., 2010). Thus, joint analysis of physical, chemical, and biological variables started to provide a more accurate answer about aquatic ecosystems' environmental quality (Lobo \& Callegaro, 2000).
Among the components that represent the aquatic biota, benthic macroinvertebrates are good indicators of water quality because they have important features, like reduced mobility, simple sampling, organisms easily identified to the family level and responding quickly to disturbances, in addition to presenting several taxa that react in different ways to various types and levels of pollution (Rosenberg \& Resh, 1993; Callisto et al., 2002; Buss et al., 2003). These characteristics have contributed to the increasingly frequent use of these organisms as biological indicators in various parts of the world such as Europe, Australia, North America, South America, and other subtropical regions (Junqueira et al., 2010).

For the assessment of water quality through the use of benthic macroinvertebrates, several indexes have been proposed. Among them, one of the most used worldwide is the BMWP ("Biological Monitoring Working Party Score System"), which 
was created in 1976 in Great Britain and has used benthic macroinvertebrates' families to assess water quality (Monteiro et al., 2008).

The $A B C$ curves is another method used to assess the environmental quality of aquatic environments (Warwick, 1986). This method compares dominance in terms of abundance and biomass, with the justification that biomass tends to be proportionally greater than the number of individuals in stable environments. In this way, in undisturbed environments, one or two taxa can be dominant in terms of biomass, raising their curves over numerical abundance. In contrast, disturbed communities have low species richness, with a high density of small body size individuals, not dominant in biomass. Thus, the numerical abundance curve overlaps that of biomass. In environments with intermediate conditions, the numerical abundance curve overlaps and can cross several times (Warwick, 1986; Magurran, 2011).

The growth of São Carlos city has caused improper use and occupation around natural areas and has had a negative impact on the Monjolinho River basin. This river is responsible for more than $20 \%$ of the water supply in this city, which justifies the constant monitoring of this area for conservation actions (Barrilli et al., 2015). Therefore, this study aims to evaluate the habitats and benthic macroinvertebrates community from the tributaries of the Monjolinho River, applying physical, chemical and biological indices of environmental quality.

\section{MATERIAL AND METHODS}

\section{Samplings}

The stretches used as sampling sites were chosen to include various environmental and anthropogenic influences (natural, rural, and urban areas) in several streams belonging to the upper portion of the Monjolinho River catchment area (Fig. 1).

A brief description of each site follows (Coordinates: SIRGAS 2000 UTM 23 S), according with Barrilli et al. (2015):

- Espraiado stream (203886.9, 7567552.3): The sampling was carried out in a section characterized by an environment of dense, structured, and closed-canopy forest, legally defined with a preservation area. This site is located on Federal University of São Carlos land, enclosed in an area covered by cerrado stricto sensu and Eucalyptus sp. forest.

- Belvedere stream (203540.41, 7564791.32): Environment with a small fragment of riparian vegetation, but with signs of burning and household waste, as well as earthworks that indicate the urban expansion.

- Ponte de Tábua stream (204482.0, 7563885.2): Environment located in an urban area, with fragments of riparian vegetation and domestic waste collected along the stretch.

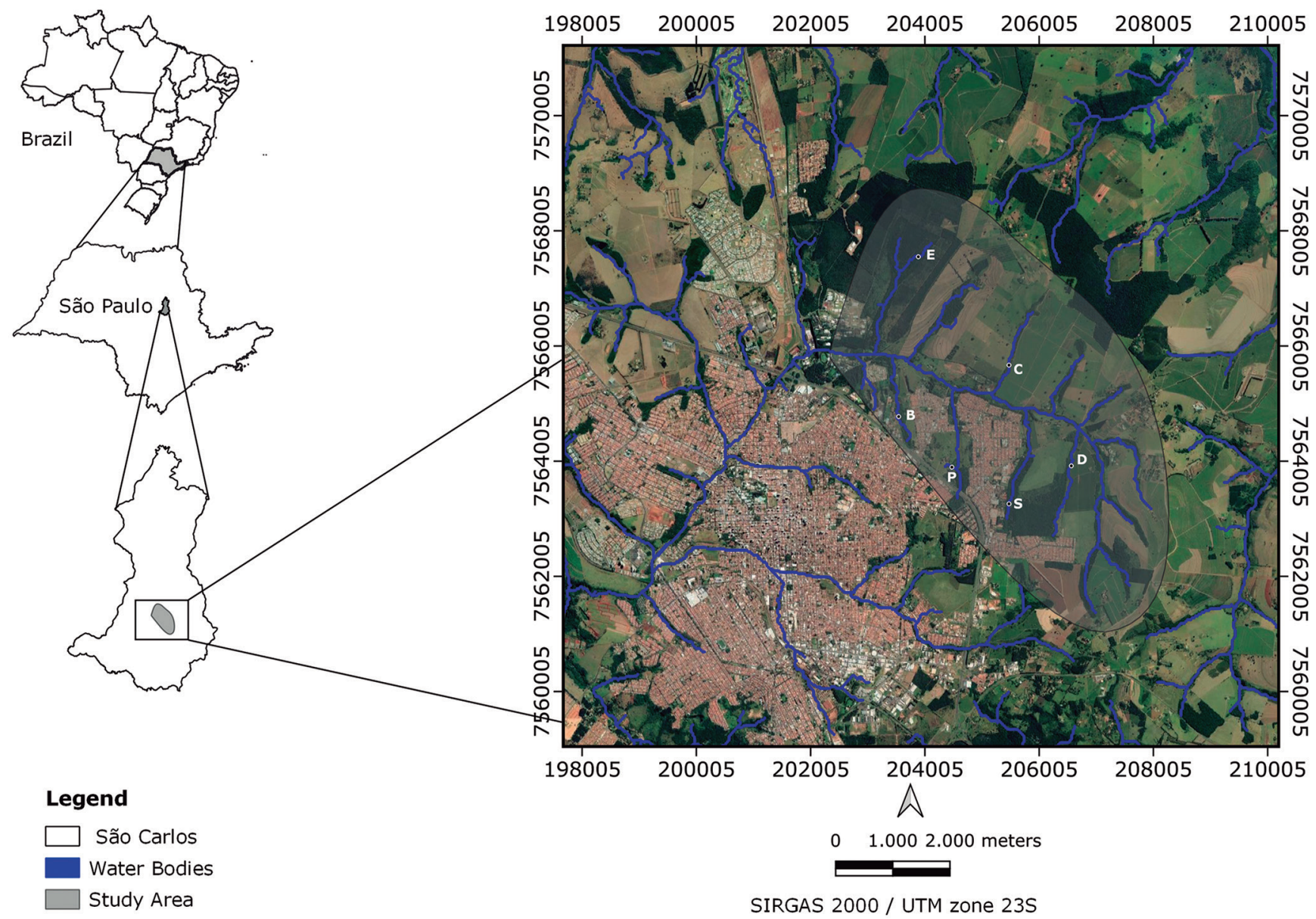

Figure 1. Map showing the sampled streams. Letters represent the following streams: $E=$ Espraiado, $B=$ Belvedere, $C=$ Canchim, $P=P$ onte de Tábua, $S=S a ̃ o$ Rafael and $\mathrm{D}=$ Douradinho. 
- Canchim stream (205482.7, 7565680.9): Environment located inside a farm, with riparian vegetation and without evidence of household wastes.

- São Rafael stream (205472.0, 7563280.3): Environment located in an urban area with evidence of disturbance.

- Douradinho stream (206570.7, 7563949.0): Environment located inside a farm, characterized by a large forest fragment.

Samples were conducted in July and August 2013. The physical and chemical data: $\mathrm{pH}$, electrical conductivity, dissolved oxygen concentration, and water temperature, were measured "in situ" with a HORIBA U-10 multiprobe, alongside the water sampling. The inorganic nutrients analyzed were: total phosphorus and nitrogen (Valderrama, 1981), nitrite (Bendchreider \& Robinson, 1952, cited by Golterman et al., 1978), nitrate (Mackereth et al., 1978), ammonium (Koroleff, 1976, cited by Mackereth et al., 1978).

\section{Environmental characterization}

The environmental characterization of the collection sites was performed using the rapid habitat diversity evaluation protocol (RHDEP) proposed by Callisto et al. (2002). This protocol considers a series of parameters based on observations of the habitat, involving vegetation cover, water and sediment conditions, and assigning scores to the environments. The following scores classify environments into Natural (above 60 points), Altered (from 41 to 60 points) or impacted (from 0 to 40 points). Once the nutrient concentrations were established, the trophic state index (TSI) of Carlson (1977) modified by Lamparelli (2004) was calculated. This index is suitable for lotic environments and allows data calculation related to chlorophyll and total phosphorus concentration (Table 1). In the absence of one of these two variables, it is recommended to use the one available (CETESB, 2007). In our study, we calculated the trophic status index using total phosphorus through the following formula, where "TP" is total phosphorus and "In" is natural logarithm:

$$
\text { TSI (TP })=10(6-((0.42-0.36(\ln T P)) / \ln 2))-20
$$

\section{Collection and analysis of benthic macroinvertebrates community}

A Suber-type sampler $\left(900 \mathrm{~cm}^{2}\right.$ and $250 \mathrm{~cm}$ mesh opening) was used to sample the benthic macroinvertebrate community. In each stream, three collection points were defined with a distance of approximately ten feet between them. Sediment samples were collected in triplicate at each collection point. To sample microhabitats and areas of difficult sampling, a scan was performed with a D-net sampler with a $0.5 \mathrm{~mm}$ mesh opening for 30 seconds on each point, with three scans in each stream. After being identified, the specimens were deposited in
Table 1. Reference values for trophic status classification (TSI). TP $=$ Total Phosphorus.

\begin{tabular}{lcc}
\hline \multicolumn{1}{c}{ Category of Trophic State } & Range & TP $\left(\mathbf{m g} . \mathbf{m} \mathbb{\Xi}^{\mathbf{3}}\right)$ \\
\hline Ultraoligotrophic & $\mathrm{TSI} \leq 47$ & $\mathrm{P} \leq 13$ \\
Oligotrophic & $47<\mathrm{TSI} \leq 52$ & $13<\mathrm{P} \leq 35$ \\
Mesotrophic & $52<\mathrm{TSI} \leq 59$ & $35<\mathrm{P} \leq 137$ \\
Eutrophic & $59<\mathrm{TSI} \leq 63$ & $137<\mathrm{P} \leq 296$ \\
Supereutrophic & $63<\mathrm{TSI} \leq 67$ & $296<\mathrm{P} \leq 640$ \\
Hypereutrophic & $\mathrm{TSI}>67$ & $\mathrm{P}>640$ \\
\hline
\end{tabular}

the Limnology laboratory of the Department of Ecology and Evolutionary Biology at the Federal University of São Carlos (DEBE - UFSCar).

The organisms were identified to the lowest possible taxonomic level, using identification keys of Righi (1984), Merritt \& Cummins (1996), Roldan-Pérez (1988), Brinkhurst \& Marchese (1992), Trivinho-Strixino \& Strixino (1995), Wiggins (1998), Epler (2001), Fernández \& Domínguez (2001), Costa et al. (2004), Salles (2006), Lecci \& Froelich (2007).

We used the biotic index "Biological Monitoring Working Party System" (BMWP) developed by AlbaTercedor \& Sánchez-Ortega (1988) and modified by Loyola (2000) to evaluate the water quality. The criteria for the classification of water quality in tributaries of the study followed the classification of Environmental Institute Paraná - IAP (2003), which takes into account the sensitivity of benthic macroinvertebrate families to environmental degradation.

The criteria for the classification of water quality in tributaries of the study followed the classification of Environmental Institute Paraná - IAP (2003), which considers the sensitivity of benthic macroinvertebrate families to environmental degradation.

For comparison among the sampled streams, the alpha diversity descriptors were calculated by species richness (S), Pielou's equitability $\left(J^{\prime}\right)$, Simpson's dominance index $\left(D^{\prime}\right)$, Shannon's index $\left(\mathrm{H}^{\prime}\right)$ as described in Magurran (2011).

\section{Benthic macroinvertebrate biovolumes}

The biovolumes were calculated from each taxon's average size, using the appropriate geometric shapes (Ruttner-Kolisko, 1977; Sun \& Liu, 2003). We assumed the biovolume as being equal to the fresh weight.

\section{The ABC curves as an indicator of disturbances in benthic macroinvertebrate community}

The $A B C$ curves (Warwick, 1986) represent the numerical abundance and biomass accumulated from all populations present in a community. The relationship between the curves is used to make inferences about the degree of environmental disturbance. Clarke (1990) introduced a statistical tool (W index) to mitigate the effect of visual interpretation. The "W index" is obtained from 
the expression $\mathrm{W}=\Sigma(\mathrm{Bi}-\mathrm{Ai}) /[50(\mathrm{~S}-1)]$, in which $\mathrm{Bi}$ is the value of the biomass of each species (i); $A i$ is the value of the abundance of each sequence of species (i), and $\mathrm{S}$ is the number of species. Positive values indicate an undisturbed environment, negative values suggest very disturbed communities, and values close to zero indicate moderate disturbances (Magurran, 2011).

\section{Statistical analysis}

Canonical Correspondence Analysis (CCA) was applied to verify the spatial correspondence between the protocol of habitat diversity, the trophic status index, and the benthic macroinvertebrate community density. The significance of the relationships obtained between the axes was evaluated using the Monte Carlo test, with 999 random permutations and a $p$-value less than or equal to 0.05 ( $p \leq 0.05$ ). The Canonical Correspondence Analysis (CCA) was performed through the CANOCO 3.12 program (Ter Braak \& Šmilauer, 2002). Finally, a Pearson's correlation matrix was generated between the environmental quality indicators to verify significant relationships between them. For this, we use the PAST statistical package v.3.16 (Hammer et al., 2001).

\section{RESULTS}

The sampling carried out between the tributary streams of the Monjolinho River resulted in a composition of 3222 individuals distributed in 84 taxa (Table 2). The Espraiado stream was the environment with the greatest diversity of species, followed by Canchim, Douradinho, Ponte de Tábua, and São Rafael. However, despite being the environment with the largest number of individuals, Belvedere presented the least diversity among the sampled streams.

The physical and chemical analyzes, the rapid habitat diversity evaluation protocol, the trophic status index and the BMWP index resulted in a gradient of environmental quality among the sampled streams (Table 3 ). The best quality stream (Espraiado) presented oxygenated and oligotrophic waters, better habitat structure and the presence of several groups of macroinvertebrates sensitive to pollution. Conversely, the worst condition stream (Belvedere) presented eutrophic waters and low oxygenation, impacted and unvegetated habitats, lower macroinvertebrate diversity, featuring the dominance of pollution-resistant groups.

The other streams were classified as altered and mesotrophic, presenting groups tolerant and resistant to environmental pollution. The $A B C$ curves (Fig. 2) indicated that the macroinvertebrate community of the most polluted stream (Belvedere) is highly disturbed, because the density curve is above the biomass, which results in a negative "W" value. In moderately polluted streams (Douradinho, Ponte de Tábua and São Rafael, except (anchim), the biomass curves are above the density curve, but less apart. This resulted in positive $\mathrm{W}$ val- ues close to zero, indicating a community response to pollution.

The canonical correspondence analysis between the indices related to habitats' physical structure, the degree of trophic state and the macroinvertebrate community showed the separation of groups defined as the range of tolerance concerning the habitats, having an explainability of $98.9 \%$ considering the two axes (Fig. 3). Thus, individuals belonging to the Ephemeroptera, Plecoptera, Trichoptera and Megaloptera groups were associated with more structured and oligotrophic habitats. Conversely, the Diptera order is more associated with more eutrophic environments and less physical habitat structure. The other groups were correlated to environments with intermediate levels of pollution and habitat structure.

Pearson's analysis (Table 4) showed negative correlations between the trophic state index and other indicators (RHDEP, BMWP, $\mathrm{H}^{\prime}, \mathrm{W}^{\prime}$ ). The largest positive $r$ value was recorded between RHDEP and BMWP index $(r=0.99)$, demonstrating that this index's high score is highly associated with the best environmental quality classified by RHDEP. However, the W index was negatively correlated to the trophic state index (TSI) and positively with the Shannon index $\left(\mathrm{H}^{\prime}\right)$, both significant.

\section{DISCUSSION}

The Monjolinho River has suffered for decades with negative impacts resulting from sewage discharge, industrial effluents and deforestation caused by the expansion of the city of São Carlos. The chemical and physical analyses of the water, conducted in the main tributaries located in São Carlos, resulted in a gradient of environmental quality (Sé, 1992; Tundisi et al., 1999; Barrilli et al., 2015).

Because it is within a conservation area, the Espraiado stream presented the best environmental quality compared to the others, with nutrient concentrations within the limits found in natural systems with little disturbance, considering the parameters described by Tundisi \& Matsumura-Tundisi (2008). This stream was classified as natural and oligotrophic, respectively by the TSI and RHPED indexes, a result similar to that found by Barrilli et al. (2015) studying the same stream. Also, this environment presents many species sensitive to pollution, such as members of the Ephemeroptera, Plecoptera, and Trichoptera groups, which reinforces its status as a conserved environment and classifies the water condition as "Great", by the BMWP index. In general, biomonitoring studies have attributed the presence of these groups to good environmental quality (Callisto et al., 2002).

Conversely, Belvedere was rated as the worst quality among the sampled streams, being classified as impacted, eutrophic and heavily polluted by RHPED, TSI and BMWP, respectively. This is due to the little riparian forest compromised by fires, domestic waste, and earthworks, contributing to a high concentration of nutrients and low oxygenation of the waters. Therefore, it is a stream with 
Table 2. Composition and biovolume of benthic macroinvertebrates from the sampled streams. Streams legend: Espraiado (E), Canchim (C), Douradinho (D), Ponte de Tábua (P), São Rafael (S) and Belvedere (B). * Biovolume not considered (collected with qualitative sampler).

\begin{tabular}{|c|c|c|c|c|c|c|c|c|c|c|c|c|c|c|c|c|c|}
\hline & & $\mathbf{E}$ & $C$ & D & $\mathbf{P}$ & $S$ & B & Biovolume $\left(\mathrm{cm}^{3}\right)$ & & & E & $\mathrm{C}$ & D & $\mathbf{P}$ & $S$ & B & Biovolume $\left(\mathrm{cm}^{3}\right)$ \\
\hline Bivalvia & & & & & & & & & Hemiptera & & & & & & & & \\
\hline Sphaeriidae & & 0 & 12 & 0 & 5 & 0 & 0 & 0.36 & Belostomatidae & & & & & & & & \\
\hline Coleptera & & & & & & & & & & Belostoma sp. & 1 & 1 & 1 & 1 & 0 & 0 & 181.4 \\
\hline Elmidae & & & & & & & & & Gerridae & & & & & & & & \\
\hline & Hexanchorus sp. & 9 & 0 & 0 & 0 & 0 & 0 & 1.13 & & Brachymetra sp. & 7 & 0 & 0 & 0 & 0 & 0 & 0.628 \\
\hline & Heterelmis sp. & 0 & 14 & 0 & 0 & 0 & 0 & 0.43 & Naucoridae & & & & & & & & \\
\hline & Macrelmis sp. & 5 & 3 & 0 & 0 & 0 & 0 & 0.12 & & Limnocoris sp. & 7 & 0 & 0 & 0 & 0 & 0 & 50.868 \\
\hline & Microcylloepus sp. & 0 & 0 & 0 & 0 & 0 & 0 & 0.37 & Pleidae & & & & & & & & \\
\hline & Xenelmis sp. & 0 & 1 & 0 & 0 & 0 & 0 & 0.06 & & Neoplea sp. & 2 & 0 & 0 & 0 & 0 & 0 & 0.628 \\
\hline Gyrinidae & & & & & & & & & Veliidae & & 1 & 4 & 0 & 0 & 0 & 0 & 0.4396 \\
\hline & Gyrinus sp. & 2 & 0 & 1 & 0 & 0 & 0 & 5.8 & Hirudinea & & 2 & 4 & 10 & 1 & 19 & 0 & 0.00625547 \\
\hline & Gyretes sp. & 0 & 0 & 0 & 0 & 0 & 0 & 5.8 & Megaloptera & & & & & & & & \\
\hline Hydrophilidae & & & & & & & & & Corydalidae & Corydalus sp. & 2 & 0 & 0 & 0 & 0 & 0 & 47.1 \\
\hline & Berosus sp. & 1 & 1 & 1 & 0 & 0 & 0 & 0.98 & Nematoda & & 0 & 0 & 6 & 0 & 0 & 0 & 0.00628 \\
\hline & Hydrophilus sp. & 1 & 0 & 0 & 0 & 0 & 6 & 3.92 & Odonata & & & & & & & & \\
\hline Lutrochidae & & & & & & & & 0 & Aeshnidae & & 0 & 0 & 0 & 0 & 0 & 1 & 7.81 \\
\hline & Lutrochus sp. & 0 & 0 & 0 & 1 & 0 & 0 & 0.99 & & Hetaerina sp. & 3 & 2 & 0 & 2 & 0 & 0 & 49.455 \\
\hline Diptera & & & & & & & & & Coenagrionidae & & & & & & & & \\
\hline Chironomıdae & & & & & & & & & & Argia sp. & 2 & 1 & 0 & 0 & 0 & 0 & 3.768 \\
\hline Chironominae & & & & & & & & & & Ischnura sp. & 0 & 0 & 1 & 0 & 0 & 0 & $*$ \\
\hline & Beardius sp. & 7 & 6 & 0 & 0 & 0 & 0 & 0.000368 & Cordulidae & & & & & & & & \\
\hline & Caladomyia sp. & 0 & 10 & 5 & 0 & 0 & 0 & * & & Neocordulia sp. & 1 & 0 & 0 & 0 & 0 & 0 & 3.768 \\
\hline & Chironomus sp. & 1 & 38 & 72 & 57 & 2 & 2205 & * & Gomphidae & & 5 & 4 & 0 & 0 & 0 & 0 & 0.9891 \\
\hline & Cryptochironomus sp. & 0 & 8 & 0 & 6 & 0 & 0 & * & Libellullidae & & 3 & 1 & 1 & 1 & 0 & 0 & 3.768 \\
\hline & Endotribelus sp. & 1 & 4 & 0 & 2 & 4 & 0 & 0.00785 & Megapodagrionidae & & 0 & 0 & 0 & 0 & 0 & 0 & \\
\hline & Microchironomus sp. & 1 & 0 & 0 & 0 & 0 & 0 & 0.0020096 & & Heteragrion sp. & 2 & 0 & 0 & 0 & 0 & 0 & 3.768 \\
\hline & Fissimentum sp. & 12 & 0 & 0 & 0 & 0 & 0 & 0.00785 & Protoneuridae & & 5 & 1 & 4 & 0 & 0 & 0 & 21.195 \\
\hline & Pelomus sp. & 1 & 2 & 0 & 2 & 0 & 0 & 0.002512 & Oligochaeta & & & & & & & & \\
\hline & Polypedilum sp. & 0 & 12 & 12 & 6 & 0 & 0 & * & Alluroididae & & 0 & 2 & 0 & 15 & 2 & 0 & 0.00490625 \\
\hline & Stenochironomus sp. & 0 & 0 & 4 & 0 & 0 & 0 & * & Naididae & & 0 & 0 & 0 & 0 & 0 & 0 & 0.23844375 \\
\hline & Tanytarsus sp. & 2 & 0 & 0 & 0 & 0 & 0 & 0.00785 & Tubificidae & & 10 & 3 & 22 & 61 & 11 & 0 & 0.23844375 \\
\hline Orthocladinae & & & & & & & & & Plecoptera & & & & & & & & \\
\hline & Cricotopus sp. & 0 & 0 & 0 & 21 & 2 & 0 & * & Gripopterygidae & & 0 & 0 & 0 & 0 & 0 & 0 & \\
\hline & Orthocladius sp. & 0 & 2 & 0 & 2 & 0 & 0 & * & & Guaranyperla sp. & 1 & 0 & 0 & 0 & 0 & 0 & * \\
\hline & Paracladius sp. & 0 & 4 & 0 & 0 & 0 & 0 & * & & Paragripopteryx sp. & 1 & 0 & 0 & 0 & 0 & 0 & * \\
\hline Tanypodinae & & & & & & & & & & Tupiperla sp. & 1 & 0 & 0 & 0 & 0 & 0 & * \\
\hline & Ablasbemyia sp. & 13 & 2 & 10 & 2 & 0 & 0 & 0.000628 & Perlidae & & 0 & 0 & 0 & 0 & 0 & 0 & \\
\hline & Clinotanypus sp. & 3 & 0 & 0 & 0 & 0 & 0 & 0.0002826 & & Kempnyia sp. & 1 & 0 & 0 & 0 & 0 & 0 & * \\
\hline & Coelotanypus sp. & 3 & 0 & 0 & 0 & 0 & 0 & 0.0002826 & & Macrogynoplax sp. & 19 & 0 & 0 & 0 & 0 & 0 & 0.5024 \\
\hline & Fittkauimyia sp. & 0 & 0 & 0 & 4 & 4 & 0 & * & Trichoptera & & & & & & & & \\
\hline & Labrundinia sp. & 2 & 0 & 0 & 0 & 0 & 0 & 0.0003533 & Calamoceratidae & & & & & & & & \\
\hline & Zavrelimyia sp. & 0 & 16 & 0 & 2 & 0 & 0 & * & & Phylloicus sp. & 13 & 1 & 0 & 0 & 0 & 0 & 22.07 \\
\hline Ceratopogonidae & & 20 & 4 & 1 & 1 & 1 & 1 & 0.0009891 & Helicopsychidae & Holiconsuchesn & & & & & & & \\
\hline Empididae & & 2 & 1 & 0 & 1 & 0 & 0 & 0.05024 & & Helicopsyche sp. & 1 & 0 & 0 & 0 & 0 & 0 & 0.628 \\
\hline Sarcophagidae & & 0 & 0 & 2 & 0 & 0 & 0 & 0.314 & Hlaropsychidae & Smicridea sn & 1 & 0 & 0 & 0 & 0 & 0 & 0.628 \\
\hline Simulidae & & 0 & 0 & 3 & 0 & 0 & 0 & 0.01884 & Leptoceridae & тітінтаеа sp. & 1 & 0 & 0 & 0 & 0 & 0 & 0.020 \\
\hline Stratiomydae & & 0 & 0 & 1 & 0 & 0 & 0 & 0.02355 & Leptocenude & Triplectides sp. & 12 & 0 & 0 & 0 & 0 & 0 & 10.676 \\
\hline Psychodidae & & 0 & 0 & 1 & 0 & 0 & 0 & 0.1099 & & Notalina sp. & 2 & 0 & 0 & 0 & 0 & 0 & 10.676 \\
\hline Tabanidae & & 12 & 0 & 1 & 1 & 0 & 0 & 0.01884 & Odontoceridae & & & & & & & & \\
\hline Tipulidae & & 15 & 4 & 10 & 1 & 1 & 0 & 0.02355 & & Barypenthu sp. & 6 & 0 & 0 & 0 & 0 & 0 & 10.597 \\
\hline Ephemeroptera & & & & & & & & & & Marilia sp. & 1 & 0 & 0 & 0 & 0 & 0 & 98.125 \\
\hline Baetidae & & 1 & 2 & 0 & 0 & 0 & 0 & 0.024 & Polycentropodidae & & & & & & & & \\
\hline Leptophlebidae & & & & & & & & & & Polycentropus sp. & 3 & 0 & 0 & 0 & 0 & 0 & 0.2041 \\
\hline & Askola sp. & 24 & 0 & 0 & 0 & 0 & 0 & 0.0187929 & & Polyplectropus sp. & 4 & 0 & 0 & 0 & 0 & 0 & 0.1884 \\
\hline & Farrodes sp. & 5 & 0 & 0 & 0 & 0 & 0 & 0.01819944 & & Cyrnellus sp. & 5 & 0 & 0 & 0 & 0 & 0 & 0.2041 \\
\hline & Massartella sp. & 3 & 0 & 0 & 0 & 0 & 0 & 5.024 & Sericostomatidae & & & & & & & & \\
\hline & Miroculis sp. & 2 & 0 & 0 & 0 & 0 & 0 & 0.018369 & & Grumicha sp. & 4 & 1 & 0 & 0 & 0 & 0 & 0.8164 \\
\hline Gastropoda & & & & & & & & & Turbellaria & & & & & & & & \\
\hline Planorbidae & & & & & & & & & & Dugesiia sp. & 3 & 6 & 50 & 9 & 1 & 0 & 0.001884 \\
\hline & Biomphalaria sp. & 0 & 0 & 2 & 26 & 0 & 0 & 11.432 & Richness & & 57 & 33 & 24 & 24 & 10 & 4 & \\
\hline Physidae & & & & & & & & & Individuals & & 279 & 177 & 222 & 218 & 472 & 2213 & \\
\hline & Physa sp. & 0 & 0 & 1 & 1 & 0 & 0 & 116.993 & $\underline{\text { Shannon }\left(\mathrm{H}^{\prime}\right)}$ & & 3.57 & 2.95 & 2.22 & 2.14 & 1.77 & 0.03 & \\
\hline
\end{tabular}


low diversity of species, where resistant groups such as those of Chironomidae (Diptera) dominate this environment. In freshwater ecosystems, Chironomidae are considered poor water quality indicators because the family is often abundant in degraded locations and they do not need great environmental demands to survive (Goulart \& Callisto, 2003; Serra et al., 2017).

The streams classified as altered and mesotrophic by the TSI and RHDEP showed differences regarding the classification proposed by the BMWP index. According to this index, the water quality in Canchim, Douradinho, São Rafael, and Ponte de Tábua are classified, respectively, as "doubtful", "polluted", "very polluted" and "very polluted". Also, a gradual drop in taxonomic diversity was observed between these streams, which can be explained by the variations between riparian vegetation and nutrient contractions between these environments, contributing to habitat diversity, species composition and, consequently, to the BMWP index score. According to Barrilli
Table 3. Environmental quality indexes, the physical and chemical variables of the sampled streams. Legend: Espraiado (E), Canchim (C), Douradinho (D), Ponte de Tábua (P), São Rafael (S), Belvedere (B), Oligotrophic (0), Mesotrophic (M) and Eutrophic (Eu)

\begin{tabular}{lcccccc}
\hline \multicolumn{1}{c}{ Variables } & E & C & D & P & S & B \\
\hline Nitrogen total $\left(\mathrm{mg} . \mathrm{L}^{-1}\right)$ & 0.21 & 0.14 & 0.41 & 0.60 & 0.81 & 1.92 \\
Phosphorus $\left(\mu \mathrm{g} . \mathrm{L}^{-1}\right)$ & 19.7 & 36.6 & 47.7 & 42.8 & 53.6 & 164.8 \\
$\mathrm{pH}$ & 6.5 & 6.9 & 7.4 & 6.9 & 6.7 & 6.9 \\
Oxygen $\left(\mathrm{mg} . \mathrm{L}^{-1}\right)$ & 8.1 & 5.7 & 8.4 & 5.4 & 5.8 & 4.0 \\
Conductivity $\left(\mu \mathrm{S} . \mathrm{cm}^{-1}\right)$ & 9.7 & 19.0 & 39.0 & 42.3 & 107.0 & 107.0 \\
Temperature $\left({ }^{\circ} \mathrm{C}\right)$ & 17.5 & 20.3 & 17.8 & 18.3 & 21.7 & 19.4 \\
TSI & 49.4 & 52.6 & 54.0 & 53.5 & 54.6 & 60.5 \\
Classification (TSI) & 0 & $\mathrm{M}$ & $\mathrm{M}$ & $\mathrm{M}$ & $\mathrm{M}$ & Eu \\
RHDEP & 83.0 & 59.0 & 57.0 & 45.0 & 42.0 & 38.0 \\
Habitat Classification & Natural & Altered & Altered & Altered & Altered & Impacted \\
BMWP & 198 & 102 & 72 & 51 & 20 & 13 \\
Water Quality & Great & Acceptable & doubtful & Polluted & Very & Heavily \\
& & & & & Polluted & Polluted \\
\hline
\end{tabular}

\section{(A) Espraiado}

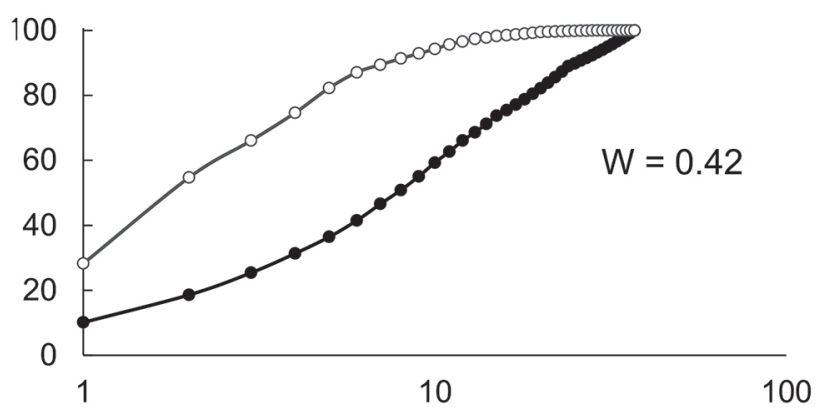

(C) Douradinho

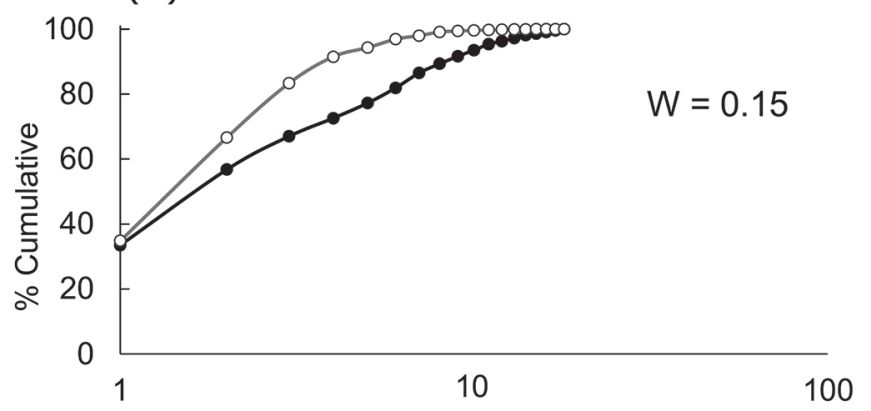

(E) São Rafael

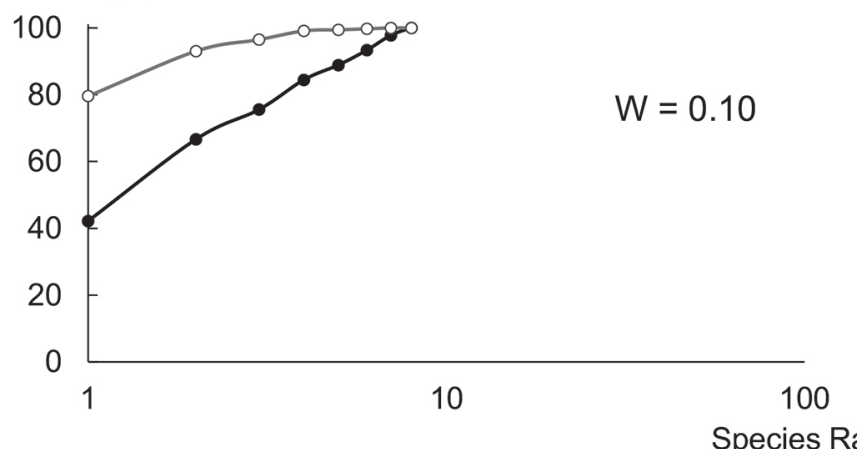

(B) Canchim

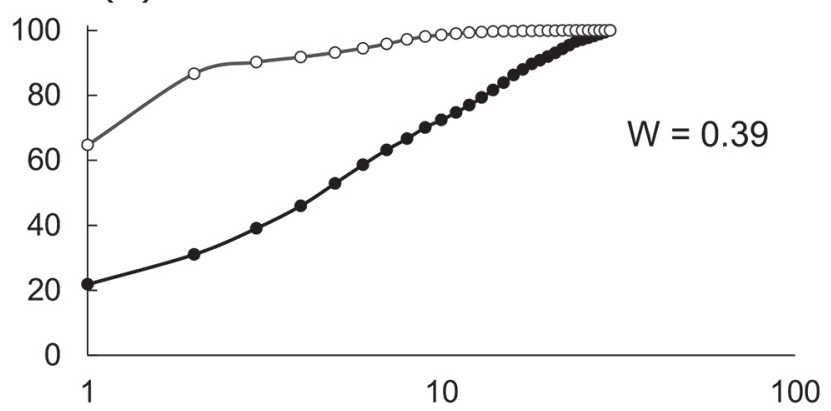

(D)Ponte de Tábua

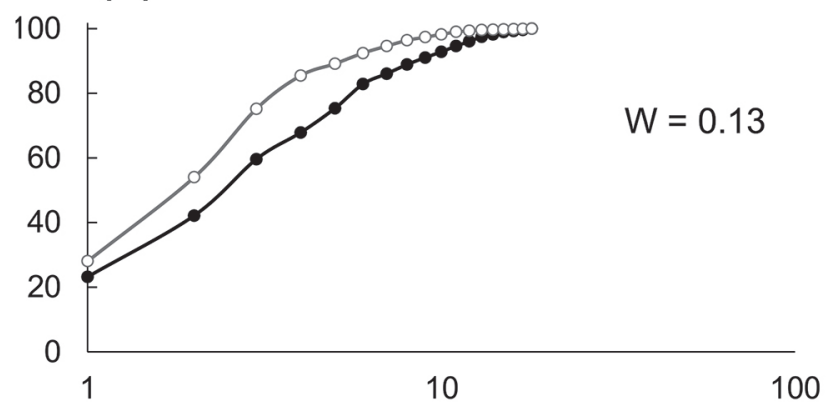

(F) Belvedere

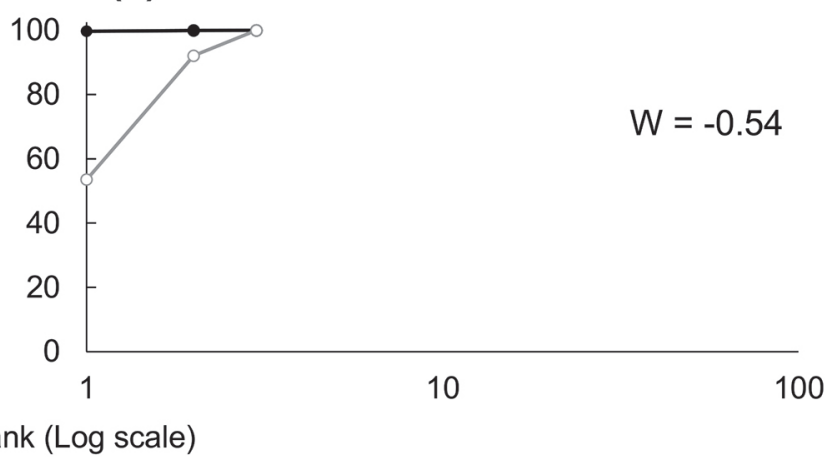

Figure 2. Abundance and Biomass Curves ( $A B C$ curves) of the sampled streams. 
Table 4. Values of Pearson's correlation ( $r$ ) and $p$-value between environmental indicators. Trophic State Index (TSI), Rapid Habitat Diversity Evaluation Protocol (RHDEP), Biological Monitoring Working Party System (BMWP), Shannon index $\left(H^{\prime}\right)$ and $W$ index. Significant values $(p<0.05)$, in bold.

\begin{tabular}{lccccc}
\hline \multicolumn{1}{c}{$\mathbf{r} / \mathbf{p}$ values } & TSI & RHDEP & BMWP & $\mathbf{H}^{\prime}$ & $\mathbf{W}^{\prime}$ \\
\hline TSI & - & $\mathbf{0 . 0 4 9 6 8}$ & $\mathbf{0 . 0 4 1 1 1}$ & $\mathbf{0 . 0 0 0 2 5}$ & $\mathbf{0 . 0 0 1 9 2}$ \\
RHDEP & -0.8006 & - & $\mathbf{0 . 0 0 0 1 4}$ & $\mathbf{0 . 0 4 4 8 9}$ & 0.10616 \\
BMWP & -0.8295 & 0.99036 & - & $\mathbf{0 . 0 3 3 7 2}$ & 0.09246 \\
H' $^{\prime}$ & -0.9871 & 0.82163 & 0.84607 & - & $\mathbf{0 . 0 0 0 4 6}$ \\
W' $^{\prime}$ & -0.9641 & 0.72065 & 0.74023 & 0.9824 & - \\
\hline
\end{tabular}

et al. (2015) and Amaral et al. (2019), streams with a more structured surrounding forest promote greater environmental heterogeneity, thus increasing the quality of habitats and species diversity.

The abundance and biomass curves $(A B C)$ indicated various levels of disturbance among the sampled streams. In the Belvedere stream, the curves indicated that this environment is very disturbed, since the abundance curve was above that of biomass and with a negative W value. In the Douradinho, Ponte de Tábua and São Rafael streams, the curves approach, resulting in a moderately disturbed environment, with the $\mathrm{W}$ value closer to zero. However, the Espraiado and Canchim streams presented the highest $\mathrm{W}$ values are undisturbed environments, with better environmental quality. Galves et al. (2007), studying tributaries with different environmental preservation characteristics in the city of Londrina, PR, verified the approximation of the biomass and density curves as the disturbance increased. In streams with better conditions, they presented the biomass curve above the density curve, and, in the polluted stream, the density curve overlapped the biomass curve.

The influence of environmental variables on the taxonomic groups assessed by the CCA demonstrated that Ephemeroptera, Plecoptera Trichoptera, Coleoptera,

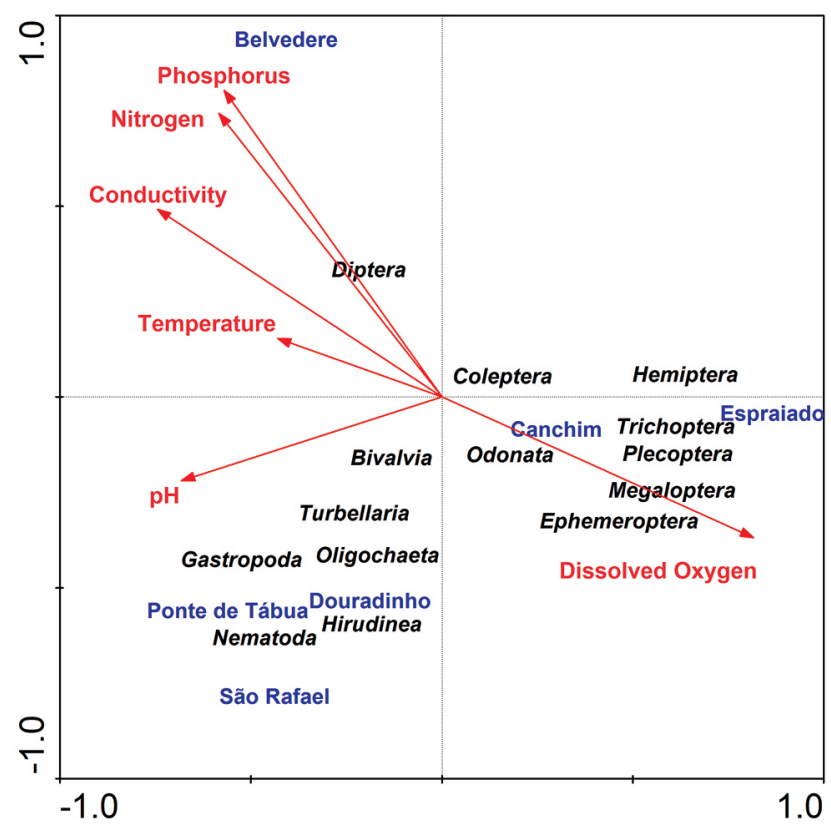

Figure 3. Canonical correspondence analysis (CCA) between the benthic macroinvertebrates groups and the water variables from the sampled streams.
Hemiptera, Odonata and Megaloptera, were positively correlated with a lower supply of nutrients and more oxygenated waters, characteristic of better environments. Conversely, the order Diptera, represented, in its majority, by the family Chironomidae, was positively correlated with waters of less oxygenation and greater concentration of nutrients, typical of more degraded and eutrophic environments. The other orders were associated with environments with moderate levels of nutrient input. According to Goulart \& Callisto (2003), the representatives of Ephemeroptera, Plecoptera and Trichoptera are characteristic of environments with high environmental quality, as they require high concentrations of oxygen dissolved in the water and a greater diversity of habitats. These same authors also affirm that the representatives of the orders Hemiptera, Odonata and Coleoptera, although typical of unpolluted environments, do not require high oxygen concentrations since these groups, including gastropods, use atmospheric oxygen. Other groups, as dipterans (Chironomidae) and Oligochaeta, can withstand severe environmental conditions.

The results generated by the correlation analysis between the disturbance indexes reinforce that eutrophication, deforestation and poor preservation of natural resources negatively affect the diversity of the aquatic biota, eliminating sensitive groups and favoring the dominance of resistant species, as also observed by Tullos \& Neumann (2006) and Sato \& Riddiford (2007) in studies involving the macroinvertebrate community. According to Kaller \& Hartman (2004), the loss of vegetation cover, agricultural activities, urbanization, among other factors, contribute strongly to the homogenization of the bed of aquatic environments, reducing habitats, micro-habitats and destabilizing the substrate, severely affecting aquatic fauna. Besides, large volumes of nutrients in the water come from sources of pollution such as discharge of sewage and untreated household waste, contributing to the process of eutrophication and loss of environmental quality (Allan \& Castillo, 2007).

\section{CONCLUSION}

The preservation of the vegetation cover contributed to the high diversity and the occurrence of sensitive groups in the Espraiado stream, indicating a better environmental quality in that place. Among the streams studied, Espraiado is probably the only one that contains a representative sample of the biota of benthic macroinvertebrates in that region. However, the high concentrations of nutrients and deforestation in the surroundings compromise the water quality, the taxonomic diversity and the establishment of sensitive species in the Belvedere, classifying it as of a lesser quality among the sampled streams. Moderately polluted streams (Canchim, Douradinho, Ponte de Tábua and São Rafael) presented gradual losses of environmental quality and sensitive species of benthic macroinvertebrates, resulting from anthropic actions. 
Finally, the biotic index (BMWP), Rapid Habitat Diversity Evaluation Protocol (RHDEP), the trophic state index (TSI) and the abundance and biomass curves proved to be efficient tools in environmental assessment. They allowed diagnosing the streams of the upper Monjolinho River, resulting in identifying very clean to severely polluted environments. Thus, considering that the water in this portion is an important resource for supplying the population, actions to clean up and recover the degraded environments are urgent and a priority for public health.

\section{ACKNOWLEDGMENTS}

We thank the Coordination of Improvement of Higher Education Personnel (CAPES) for the financial support.

\section{AUTHORS' CONTRIBUTIONS}

All authors actively participated in discussing the results, reviewed and approved the final version of the article. G.H.C.B.: conceptualization, methodology, software, formal analysis, investigation, original draft, writing, review \& editing and validation; N.F.N.: investigation, methodology and writing, review \& editing and validation; O.R. and J.R.V.: conceptualization, writing, supervision, resources, review \& editing and validation.

\section{REFERENCES}

Alba-Tercedor, J. \& Sánchez-Ortega, A. 1988. Um método rápido y simple para evaluar la calidade biológica de las aguas corrientes basado em el de Hellawell (1978). Limnética, 4: 51-56.

Allan, J.D. \& Castillo, M.M. 2007. Stream ecology structure and function of running waters. 2.ed. Dordrecht, Springer.

Amaral, P.H.M.; de Almeida Gonçalves, E.; da Silveira, L.S. \& da Gama Alves, R. 2019. Richness and distribution of Ephemeroptera, Plecoptera and Trichoptera in Atlantic forest streams. Acta Oecologica, 99: 103441. DOI

Barrilli, G.H.C.; Rocha, 0.; Negreiros, N.F. \& Verani, J.R. 2015. Influence of environmental quality of the tributaries of the Monjolinho River on the relative condition factor $(\mathrm{Kn})$ of the local ichthyofauna. Biota Neotropica, 15(1): e20140107. EPub June 19, 2015. DOI

Brinkhurst, R.0. \& Marchese, M. 1992. Guía para la identificación de oligoquetos acuáticos continentales de Sudy Centroamérica. 2.ed. Santo Tomé, Argentina, Asociación de Ciencias Naturales del Litoral. (Colección (limax 6).

Buss, F.D.; Baptista, D.F. \& Nessimian, J.L. 2003. Bases conceituais para a aplicação de biomonitoramento em programas de avaliação da qualidade da água de rios. Cadernos de Saúde Pública, Rio de Janeiro, 19(2): 465-473.

Callisto, M.; Ferreira, W.; Moreno, P.; Goulart, M. \& Petrucio, M. 2002. Aplicação de um Protocolo de Avaliação Rápida da Diversidade de Habitats em Atividades de Ensino e Pesquisa (MG-RJ). Acta Limnologica Brasiliensia, (14): 91-98.

Clarke, K.R. 1990. Comparison of dominance curves. Journal of Experimental Marine Biology and Ecology, (138): 143-157. D0I
Companhia Ambiental do Estado de São Paulo (CETESB). 2007. Relatório de Qualidade das Águas Interiores no Estado de São Paulo: 2006. São Paulo, CETESB, 2007. (Série Relatórios).

Costa, J.M.; Souza, L.0.I. \& Oldrini, B.B. 2004. Chave para identificação das famílias e géneros das larvas conhecidas de Odonata do Brasil : comentários e registros bibliográficos (Insecta, Odonata). Publicações Avulsas do Museu Nacional, 99: 1-44.

Epler, J.H. 2001. Identification manual for the larval Chironomidae (Diptera) of North and South Carolina. North Carolina Departament of Environmental and Natural Resources - Division of Water Quality.

Fernández, H.R. \& Domínguez, E. 2001. Guía para la determinación de los artrópodos bentónicos sudamericanos. Argentina, Facultad de Ciencias Naturales e Instituto M. Lillo. Universidad Nacional de Tucumán.

Galves, W.; Jerep, F.C. \& Shibatta, 0.A. 2007. Estudo da condição ambiental pelo levantamento da fauna de três riachos na região do Parque Estadual Mata dos Godoy (PEMG), Londrina, PR, Brasil. Pan-American Journal of Aquatic Siences, 2(1): 55-65.

Golterman, H.L.; Clymo, R.S. \& Ohnstad, M.A.M. 1978. Methods for Physical and Chemical Analysis of Fresh Waters, 2 ed. Oxford, Blackwell Scientific Publications. 215p.

Goulart, M.D. \& Callisto, M. 2003. Bioindicadores de qualidade de água como ferramenta em estudos de impacto ambiental. Revista FAPAM, 2(1).

Hammer, Ø.; Harper, D.A.T. \& Ryan, P.D. 2001. PAST: Paleontological statistics software package for education and data analysis. Palaeontologia Electronica, 4(1): 1-9. Avaliable: http://palaeo-electronica.org/2001 1/ past/issue1 01.htm. Access: 18/06/2021.

Instituto Ambiental do Paraná (IAP). 2003. Relatório anual. Curitiba, Contrato Itaipu Binacional, Instituto Ambiental do Paraná. Estudos Limnológicos do Reservatório de Itaipu.

Junqueira, M.V.; Friedrich, G. \& Araújo, P.R.P. 2010. A saprobic index for biological assessment of river water quality in Brazil (Minas Gerais and Rio de Janeiro states). Environmental Monitoring and Assessment, 163: 545-554. PMid:19387856. DOI

Kaller, M.D. \& Hartman, K.J. 2004. Evidence of a threshold level of fine sediment accumulation for altering benthic macroinvertebrate communities. Hydrobiologia, 518: 95-104.

Lamparelli, M.C. 2004. Graus de trofia em corpos d'água do estado de São Paulo: avaliação dos métodos de monitoramento. 238p. Tese de Doutorado. Universidade de São Paulo.

Lecci, L.S. \& Froelich, C.G. 2007. Plecoptera. In: Froelich, C.G. (Ed.). Guia online: Identificação de larvas de Insetos Aquáticos do Estado de São Paulo. Avaliable: http://sites.ffclrp.usp.br/aguadoce/guiaonline. Access: 18/06/2021.

Lobo, E.A. \& Callegaro, V.L. 2000. Avaliação da qualidade de águas doces continentais com base em algas diatomáceas epilíticas: Enfoque metodológico. In: Tucci, C.E.M. \& Marques, D.M. (Orgs.). Avaliação e controle da drenagem urbana. Porto Alegre, Editora da Universidade/ UFRGS, 2000.

Loyola, R.G.N. 2000. Atual estágio do IAP no uso de índices biológicos de qualidade. In: Anais do V Simpósio de Ecossistemas Brasileiros de Conservação. São Paulo, ACIESP.

Mackereth, F.J.H.; Heron, J. \& Talling, J.F. 1978. Water Analysis: Some Revised Methods for Limnologists. Freshwater Biological Association. Kendall, Titus Wilson \& Son. 117p. (Scientific Publication, 36)

Magurran, A.E. 2011. Medindo a diversidade biológica. Oxford, Blackwell Publishing.

Merritt, R.W. \& Cummins, K.W. 1996. An introduction to the aquatic insects of North America. 3.ed. Dubuque, Kendall/Hunt.

Monteiro, T.R.; Oliveira, L.G. \& Godoy, B.S. 2008. Biomonitoramento da qualidade de água utilizando macroinvertebrados bentônicos: 
Adaptação do índice biótico BMWP' à bacia do rio Meia Ponte-G0. Oecologia Australis, 12(3):553-563. D01

Righi, G. 1984. Oligochaeta. In: Schaden, R. (Ed.). Manual de identificação de invertebrados límnicos do Brasil. Brasilia, CNPq.

Roldan-Pérez, G.R. 1988. Guía para el estudo de los macroinvertebrados acuáticos del Departamento de Antioquia. Colômbia, Universidade de Antioquia. 217p.

Rosenberg, D.M. \& Resh, V.H. 1993. Freshwater biomonitoring and benthic invertebrates. New York, Chapman and Hall.

Ruttner-Kolisko, A. 1977. Suggestions for biomass calculations of plankton rotifers. Archiv für Hydrobiologie, 8: 71-76.

Salles, F.F. 2006. A ordem Ephemeroptera no Brasil (Insecta): taxonomia e diversidade. Tese de doutorado. Viçosa, Universidade Federal de Viçosa.

Sato, M. \& Riddiford, N. 2007. A preliminary study of the Odonata of S'Albufera Natural Park, Mallorca: status, conservation priorities and bio-indicator potential. Journal Insect Conservation, 12(5): 539-548. D0I

Sé, J.A.S. 1992. 0 rio Monjolinho e sua bacia hidrográfica como integradores de sistemas ecológicos: um conjunto de informações para o início de um processo de pesquisas ecológicas, de educação e gerenciamento ambientais a longo prazo. Dissertação de Mestrado, Universidade de São Paulo, São Carlos, Brasil.

Serra, S.R.Q.; Graça, M.A.S.; Dolédec, S. \& Feio, M.J. 2017. Chironomidae traits and life history strategies as indicators of anthropogenic disturbance. Environmental Monitoring and Assessment, 189(7). DOI

Siqueira, T. \& Roque, F.0. 2010. Normatização de Dados de Biodiversidade para Gestão de Águas. Brazilian Journal of Nature Conservation. Natureza \& Conservação, 8(2): 190-193.

Stevenson, R.J.; Boththwel, M.L. \& Lowe, R.L. 1996. Algal Ecology. Freshwater Benthic ecosystems. San Diego, Academic Press. 752p.
Sun, J. \& Liu, D. 2003. Geometric models for calculating cell biovolume and surface area for phytoplankton. Journal of Plankton Research, 25: 1331-1346.

Suriano, M.T.; Fonseca-Gessner, A.A.; Roque, F.O. \& Froehlich, C.G. 2010. Choice of macroinvertebrate metrics to evaluate stream conditions in Atlantic Forest, Brazil. Environmental Monitoring and Assessment, 175: 87-101. DOI.

Ter Braak, C.J.F. \& Šmilauer, P. 2002. CANOCO reference manual CanoDraw for Windows user's guide: software for canonical community ordination (version 4.5) - Microcomputer Power Ithaca, NYUS. 500p.

Trivinho-Strixino, S. \& Strixino, G. 1995. Larvas de Chironomidae (Diptera) do Estado de São Paulo: guia de identificação de diagnose dos gêneros. Programa de Pós-Graduação em Ecologia e Recursos Naturais, Universidade Federal de São Carlos, São Carlos. 229p.

Tullos, D.D. \& Neumann, M. 2006. A qualitative model for analyzing the effects of anthropogenic activities in the watershed on benthic macroinvertebrate communities. Ecological Modelling, 196(1-2): 209-20.

Tundisi, J.G. \& Matsumura-Tundisi, T.M. 2008. Limnologia. São Paulo, Oficina de Textos. 632p.

Tundisi, J.G.; Matsumura-Tundisi, T. \& Rocha, 0. 1999. Theoretical basis for reservoir management. In: Tundisi, J.G. \& Straskraba, M. Theoretical reservoir ecology and its application. São Carlos, SP International Institute of Ecology.

Valderrama, J.C. 1981. The simultaneous analysis of total nitrogen and phosphorus in natural water. Marine Chemistry, 10: 109-122. D0l

Warwick, R.M.A. 1986. A new method for detecting pollution effects on marine macrobenthic communities. Marine Biology, v. 92(4):557-562. D0I

Wiggins, B.G. 1998. Larvae of the North American caddisfly genera (Trichoptera). 2. ed. Toronto, University of Toronto. 